\title{
TOPOGRAFIA RZYMSKIEJ TARRAGONY W ŚWIETLE ŹRÓDEŁ PISANYCH I ARCHEOLOGICZNYCH
}

\author{
Anna Zimnowodzka*
}

\begin{abstract}
The origins of Roman Tarragona reach back to the $3^{\text {rd }}$ century, when - in 218 BC - the Romans set up a military camp on the location of the Iberian oppidum of Kese/Cese. Its strategic layout was appreciated by the Roman commanders during the Punic Wars and throughout the conquest of Iberian Peninsula. In the 1st century BC, Tarragona became a Roman colony (colonia Iulia Urbs Triumphalis Tarraco) and in $27 \mathrm{BC}$ - a province, which resulted in dynamic urban development. The prosperity of Tarraco reached its climax at the beginning of the $2^{\text {nd }}$ century $\mathrm{AD}$, when many important administrative and religious buildings, as well as places of public entertainment, such as a theatre, an amphitheater and a circus, were erected. The second half of the $2^{\text {nd }}$ century brought a slowdown in urban development, both inside the city walls and behind them. In the $3^{\text {rd }}$ century, just outside the walls, a large necropolis grew, which in 258 became a burial ground for the ashes of Bishop Fructuosus and his deacons, martyred in the local amphitheater. In the $4^{\text {th }}$ century, a vast pilgrimage center arose around the martyrs' tomb, attracting worshippers from all over the Christian world. The next century brought many changes in numerous aspects of the city. The monumental Roman edifices ceased to perform their civic and religious functions. Along with the increasing importance of the
\end{abstract}

\footnotetext{
* Katolicki Uniwersytet Lubelski Jana Pawła II, Wydział Nauk Humanistycznych, Instytut Historii Sztuki, Katedra Historii Sztuki Wczesnochrześcijańskiej i Tradycji Antycznej, Al. Racławickie 14, 20-950 Lublin,azimnowodzka@go2.pl.
} 
Christian faith and the cult of martyrs, churches and monasteries were erected one by one, first on the outskirts of the city and then, from the $6^{\text {th }}$ century onwards, also inside the city walls.

Keywords: topography, amphitheater, circus, altar, temple, church.

Słowa kluczowe: topografia, amfiteatr, cyrk, ołtarz, świątynia, bazylika.

Początki Tarragony sięgają III wieku p.n.e. W zimie 218 roku p.n.e. Rzymianie pod dowództwem Gnejusza Korneliusza Scypiona dopłynęli do miasta Empurion i kierując się na południe, zajęli niewielkie iberyjskie oppidum Kese/Cese $e^{1}$ zalążek przyszłej Tarraco. Jak wspomina Polibiusz (200-118 r. p.n.e):

Gnejusz Korneliusz [...] zawinął w Iberii w pobliżu tak zwanego Emporium. Od ego miejsca począwszy wysadzał wojsko na ląd; i te miasta pobrzeżne aż do rzeki Iber [Ebro], które odmawiały mu posłuszeństwa, oblegał, te zaś, które go przyjmowały, traktował po ludzku i okazywał im wszelkie możliwe staranie. [...]. Gdy zaś Kartagińczycy [...] koło miasta Kesse stanęli naprzeciw niego obozem, Gnejusz wydał im regularną

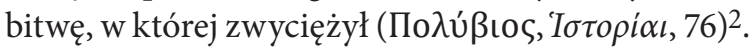

Od tego czasu miasto to nazywał Tarraco, a na wzgórzu, które nad nim górowało założył obóz wojskowy, gdzie „trzymając już razem lądowe i morskie wojsko spędzał zimę" (Polibiusz, 2005: $76)^{3}$. Korzystając $z$ dorobku Polibiusza, w podobny sposób wydarzenia te opisuje Tytus Liwiusz. Iberyjskie założenie nazywa Cysse (Titus Livius, Ab Urbe condita libri, 21, 60) ${ }^{4}$, a od czasu odniesionego tam przez Rzymian zwycięstwa określa je jako Tarraco (Mar et al., 2010: 39).

W roku 217 p.n.e., wraz z przybyciem brata Gnejusza Scypiona - Publiusza Korneliusza Scypiona, Tarraco stało się strategicz-

1 Założone prawdopodobnie w V wieku p.n.e. (Mar et al., 2010: 39).

2 Cyt. za: Polibiusz, 2005: 158.

3 Ibidem, s. 158 i n.

4 Tytus Liwiusz, 1974: 61. 
ną bazą wojskową wykorzystywaną do walk z Kartagińczykami na czas drugiej wojny punickiej (218-201 r.p.n.e) (Mar et al., 2010: $21,61)^{5}$. Od czasu przybycia tego drugiego Pliniusz Starszy nazywa Tarraco - Scipionum opus (Gaius Plinius Secundus, HN, 3, 4) ${ }^{6}$. Po trwającej kilkanaście lat drugiej wojnie punickiej, Rzymianie utrzymali założony na górującym nad Kesse (il. 1) wzgórzu obóz wojskowy, gdzie miały stacjonować wojska (Mar et al., 2010: 39 i n; Mar et al., 2015a: 68). Zdecydowały o tym również dogodne warunki topograficzne u podnóża wzniesienia, sprzyjające rozwojowi portu (Ruiz de Árbulo Bayona, 2001-2002: 87-107). Jego obecność miała kluczowy wpływ na rozwój późniejszego miasta, stanowił on bowiem bazę przerzutową wojsk z Rzymu na tereny Półwyspu. Powołując się na geografów greckich Eratostenesa z III wieku p.n.e. i Artemidora z Efezu z przełomu II-I wieku p.n.e., Strabon pisze, że ten pierwszy był pod wrażeniem organizacji portu w Tarraco, posiadającego obszerną redę, umożliwiającą zakotwiczenie statków oczekujących na wejście do portu. Artemidor natomiast, na którego powołuje się w dalszej części tekstu Strabon, twierdził, że było to zaledwie kotwicowisko (Strabon, 3, 4, 7, szerzej na ten temat: Ruiz de Árbulo Bayona, 2001-2002: 87-107; Terrado Ortuño, 2015: 237 i n.). Nie ma jednak wątpliwości, że port odegrał kluczową rolę podczas rzymskiego podboju Hispanii. Liwiusz pisze, że w 217 roku p.n.e. przynajmniej trzydzieści longae naves rzuciło kotwice w porcie, oraz wiele innych statków, które przywiozły osiem tysięcy żołnierzy rzymskich i żywność do tej krainy (Tytus Liwiusz, 88 i n.). Po raz kolejny wojska rzymskie przybiły do portu w Tarraco w 211 roku p.n.e. w liczbie dwóch legionów oraz ponad trzynastu tysięcy żołnierzy?

5 Ibidem, s. 62. Autor przyznaje również, że Rzymianie powrócili do Tarragony, by tam spędzić zimę: „Tarraconem in hiberna reditum est”. Zob. Titus Livius, Ab Urbe condita libri, 21, 61.

6 Cyt. za: K[aja] Pliniusza Starszego Historyi naturalnej ksiag XXXVII, 1845: 20 i n. Szerzej na ten temat Járrega Domínguez, 2004: 24; Mar et al., 2015a: 27.

7 „Senat rzymski [...] przydzielił Gajuszowi Neronowi z tych dwóch legionów, które miał pod Kapuą, sześć tysięcy piechoty i trzystu konnych, których sam sobie miał wybrać, a ze sprzymierzeńców 
O tym, jak port mógł wyglądać, dowiadujemy się między innymi z opisów lokalnego entuzjasty starożytnej Tarragony - Lluísa Pons d'Icarta (1518/1520-1578) (Pons d'Icart, 1572/73: 240 i n.). Tego, że znajdował się przy niewielkiej zatoczce w pobliżu ujścia rzeki Tulcis (Francolí), i że był wyposażony w pirs portowy, dowodzą także ryciny pozostawione przez holenderskiego artystę Antona van den Wyngaerdego oraz materiały kartograficzne z XVII, XVIII i początku XIX wieku (Mar et al., 2015a: 180-186; Pociña López, Remolà Vallverdú, 2001: 85-96; Remolà Vallverdú, 2007: 47-65; Serra Masdeu, 2014). Na podstawie prac prowadzonych ostatnio w dzielnicy portowej udało się ustalić, że głębokość redy portowej wahała się między dziewięć a jedenaście metrów, a jej obszar zajmował między piętnaście a siedemnaście hektarów ${ }^{8}$. W wyniku stopniowego zamulania ujścia rzeki Tulcis (Francolí), a także prac urbanizacyjnych prowadzonych tam w XIX wieku, po starożytnym porcie (w okolicach obecnego Placu dels Carros) zostało bardzo niewiele (Terrado Ortuño, 2015: 237; Macias Solé, Remolà Vallverdú, 2010: 129-140).

Na dynamiczny rozwój miasta w II wieku p.n.e. z pewnością miało wpływ wydarzenie z 197 roku p.n.e. Wtedy to zajęte do tego czasu przez Rzymian tereny na Półwyspie zostały podzielone na dwie prowincje: Citerior i Ulterior. Tarraco otrzymała uprzywi-

latyńskich taką samą ilość piechoty i ośmiuset konnych. Wojsko to Neron wsadził w Puteolach na okręty i przerzucił się z nim do Hiszpanii. Tu przybił z okrętami do Tarrakony [...]” (cyt. za: Tytus Liwiusz, 299).

8 Ostatnie prace $\mathrm{w}$ dzielnicy portowej $\mathrm{w}$ Tarragonie prowadzono w ramach europejskiego projektu „Portuslimen - Rome's Mediterranean Ports” (2015-2019), podczas którego badaniom poddano trzydzieści portów rzymskich na Morzu Śródziemnym; zob. http:// www.icac.cat/actualitat/noticies/2017/delimitada-la-fondaria-i-els-limits-del-port-de-la-tarragona-romana/ [24.11.2017]. Rezultaty badań dotyczących starożytnego portu w Tarraco omawiano na międzynarodowym seminarium, zorganizowanym przez Instituto Catalán de Arqueología Clásica (ICAC) w Tarragonie 8.02.2017; zob. http://www.icac.cat/wp-content/uploads/2016/12/43_sem_ port.pdf [24.11.2017]. 
lejowaną pozycję „centrum polityczno-administracyjnego” prowincji Hispania Citerior ${ }^{9}$. Przez cały II wiek p.n.e. organizacja założenia miejskiego Tarraco-Kesse skoncentrowana była wokół dwóch obszarów: założonego na wzniesieniu obozu wojskowego oraz ibero-rzymskiej civitas, rozwijającej się u jego podnóża (Mar et al., 2015a, s. 81). Jak pokazują wyniki badań archeologicznych, w pierwszej połowie II wieku p.n.e. wokół castrum wzniesiono wyposażone w cztery wieże cyklopowe mury obronne. Objęły one swym zasięgiem obszar około pięciu czy sześciu hektarów ${ }^{10}$. Z pierwszego okresu pochodzą fragmenty murów między datowanymi na ten sam czas trzema wieżami Torre de Minerva, Torre del Cabiscol oraz między Torre de Arzobispo i XVI-wiecznym Fortín de Santa Bárbara (Hauschild, 1983b: 103; Aquilué Abadias et al., 1991: 271-301, il. 1) ${ }^{11}$.

W drugiej połowie II wieku p.n.e. (150-125 rok p.n.e.) obszar ten znacznie poszerzono, a mury wzniesiono również wokół obszaru poniżej wzgórza (Mar et al., 2015: 81, 86; Ruiz de Árbulo Bayona, 2015a: 140-143. W obrębie dolnej części miasta rozpoczęły się prace urbanizacyjne (il. 1). Przecinająca Tarraco z północnego wschodu na południowy zachód Via Herculea (późniejsza Via Augusta) oraz droga łącząca castrum z obiektami portowymi stały się zalążkiem późniejszych ulic miasta (Mar et al., 2015a: 106.),

9 Jeszcze pod koniec XIX wieku uważano, że stolicą mogła być Carthago Nova, a status stolicy przypadł Tarraco dopiero po pierwszej wizycie Augusta w mieście (w latach $27-25$ p.n.e.). Obecnie badacze podejrzewają, że ze względu na walory strategiczne, polityczne i ekonomiczne to Tarraco była od początku „centrum polityczno-administracyjnym" prowincji Citerior. Zob. Arrayas Morales, 2004: 293; Díaz García, 1997-1998: 122; Martínez Gázquez, 1987: 81; Ruiz de Árbulo, 1992: 127 i n.

10 Odtworzenie orientacyjnego przebiegu murów było możliwe dzięki opisom Ponsa d'Icarta, szkicom Antona van den Wyngaerdego, badaniom kartograficznym oraz archeologicznym; zob. Pons d'Icart, 1572/73: 104 i n., Remolà Vallverdú, 2010: 57; Macias Solé et al., 2010: 51; Mar et al., 1997-1998: 122 i n.

11 Wieże na ilustracji są zaznaczone ciemniejszym kolorem wraz z zachowanymi częściami murów. 
pod którymi znalazła się sieć kanalizacji miejskiej. Najważniejszą rolę odgrywał tu największy kanał odprowadzający nieczystości do morza zlokalizowany pod drogą łączącą castrum z portem (Mar et al., 2015a: 156; Díaz García, 1997-1998: 125 i n.).

Na podstawie ostatnio prowadzonych prac w południowo-zachodniej części miasta udało się zlokalizować forum miasta (Mar et al., 2015a: 156; 162 i n.; Mar et al., 2010a: 39-70; Mar et al., 2014:37-68) (il. 2). Na powstałym pod koniec II wieku p.n.e. placu wzniesiono w połowie I wieku (50-25 rok p.n.e.) szeroką na niemal trzydzieści metrów (29,79 m) świątynię kapitolińską z trójdzielną cellą, która w okresie republikańskim była dwukrotnie przebudowywana.

W I wieku p.n.e., prawdopodobnie w roku 49 r., Tarraco została przez Juliusza Cezara wyniesiona do rangi kolonii rzymskiej colonia Iulia Urbs Triumphalis Tarraco (Bravo Bosch, 2008: 109, przyp. 11; García y Bellido, 1959: 459). Nazwa ta jest potwierdzona w materiale numizmatycznym datowanym na okres od 2 roku p.n.e. do 4 roku n.e. (Ruiz de Árbulo, 2002: 139). W praktyce oznaczało to, że wkrótce w nowo powstałej kolonii miały pojawić się „te same instytucje, budowle reprezentacyjne i miejsca kultury, co w mieście macierzystym" (Grimal, 1970: 8), czyli w Rzymie. Mając status kolonii, Tarraco pełniła także rolę centrum administracyjnego dla podlegającego jej podmiejskiego terytorium (Keay, 2004: 97-110). Nie tylko zatem w centrum nowej kolonii zaczęły pojawiać się nowe obiekty, budowano je również w promieniu kilkunastu lub kilkudziesięciu kilometrów od niej12. Wśród najbardziej emblematycznych, zachowanych do naszych czasów, znajdują się głównie obiekty powstałe wzdłuż zreformowanej w czasie rządów Augusta drogi Via Augusta, między innymi Torre de los Escipiones (poł. I wieku p.n.e.; Gamer, 1981: 71-94; Gris Jeremias, Ruiz de Ârbulo Bayona, 2015: 38-50; Mar et al., 2015a: 34-37), Łuk tryumfalny w Bará (13 rok p.n.e; Dupré i Raventós, 1994; Mar et al., 2015a:37-41), wille podmiejskie w Els

12 Status ten oznaczał, że miasto cieszyło się dużą autonomią, nie dysponujemy jednak konkretną wiedzą na temat terytorium, które faktycznie podlegało jurysdykcji zarządcy miasta. 
Munts (Anton Remolà Vallverdú, 2007: 95-117; Tarrats Bou et al., 2007: 213-228) i Centcelles (Mar et al., 2015a: 16; Remolà Vallverdú, 2007: 171-189). W zasięgu terytorium kolonii znalazł się również wykorzystywany już od II wieku p.n.e. kamieniołom El Médol, w którym wydobywano wysokogatunkowy wapień wykorzystywany do wznoszenia budowli w Tarraco (Mar et al., 2015a: 63-65; López Vilar, 1990: 99-102; López Vilar, Gutiérrez García-Moreno, 2016: 177-195).

W 27 roku p.n.e. Oktawian August dokonał podziału Półwyspu na trzy nowe prowincje: Lusitania, Baetica, Tarraconensis. Status stolicy tej ostatniej otrzymała Tarraco (Bravo Bosch, 2008: 122-132; Mar et al., 2015a: 222-224). Do jej zarządzania cesarz wyznaczył namiestnika, któremu nadał tytuł legatus Augusti pro praetore (Mar et al., 2015a: 224 i n.). Jego siedziba znajdowała się $\mathrm{w}$ praetorium consulare, o czym wiadomo z jednej inskrypcji ${ }^{13}$.

Rozwój kolonii nie byłby możliwy bez rozwiązania problemu dostarczania wody do miasta. Dotychczasowe rozwiązania, polegające na wykorzystaniu wód podziemnych poprzez instalację studni i cystern, okazały się w tym czasie niewystarczające (Ruiz de Árbulo et al., 2015: 125). Od czasów Augusta problem ten miały rozwiązywać akwedukty doprowadzające wodę do miasta z odległych ujęć wodnych rzeki Tulcis (Francolí) oraz Gaia (López Vilar, Gorostidi, 2015: 251). Do dzisiaj można oglądać imponujący fragment akweduktu Les Ferreres, znanego jako Puente del Diablo, który doprowadzał wodę z górnych partii rzeki Tulcis (Mesas Torronteras, 2015: 245-250, Ruiz de Árbulo et al., 2015: 117-137, il. 3).

Pod koniec I wieku p.n.e. (po 31 roku p.n.e.) w pobliżu forum wzniesiono teatr - pierwszą budowlę dedykowaną obywatelom miasta, służącą celom rozrywkowym (Mar et al., 1993: 11-23; Ventura, 1943: 196-202; Mar et al., 2010: 173-201; Gris Jeremias

13 Z treści inskrypcji nie wynika jednak, w której części miasta znajdowała się ta budowla; "I(ovi) O(ptimo) M(aximo) / Iunoni / Minervae / Genio praetorii / consularis / diis Penatibus / T(itus) Fl(avius) Titianus / leg(atus) Augg(ustorum) pr(o) pr(aetore) / Postumia S[i]ria / eius / dicaverunt)", cyt. za: CIL II 4076 = RIT 34; na ten temat zob. Ruiz de Árbulo, 2011-2012: 563; Ruestes i Bitrià, 2001: 117. 
et al., 2015: 211-220) (il. 2). Badania dekoracji frons sceane pozwoliły ustalić, że około 4 roku był już ukończony (Mar et al., 2015a: 321). Mógł pomieścić od czterech do pięciu tysięcy widzów.

Ogromny wpływ na rozwój Tarraco miał pobyt samego Oktawiana Augusta w mieście. Cesarz przebywał w Tarragonie między 26 a 24 rokiem p.n.e. Wtedy to, w wyniku prowadzonych w północnej części Półwyspu wojen kantabryjskich, „złożony chorobą z powodu nadmiernego wysiłku i osłabionego morale wycofał się [z pola walki] do Tarraco na rekonwalescencję"14. Za czasów cesarza Augusta forum miasta zostało powiększone o przylegający doń kolejny plac, na którym wzniesiono bazylikę, pełniącą funkcję kurii lub trybunału (Ruiz de Árbulo Bayona, 1990: 119-138) (il. 2). Na pozostałości tej pokaźnej budowli natrafił w latach dwudziestych XX wieku (1926-1929) Joan Serra Vilaró (Serra Vilaró, 1932; Ruiz de Árbulo Bayona, 1990: 120; Mar et al., 2010: 42 i n.). Badaczom udało się ustalić, że była to trójnawowa budowla, długa na sześćdziesiąt i szeroka na piętnaście metrów. W tym samym czasie dobudowano do niej otoczony $\mathrm{z}$ trzech stron portykiem plac (Mar et al., 2010a: 43). Być może to właśnie tam udawał się podczas swego pobytu August, by słuchać z zamiłowaniem przemów niejakiego Gawiusza Silona, o czym wspomina Seneka (Marcus Annaeus Seneca, Controversiae, 10, 14). Pobyt cesarza w Tarraco usiłowali umilić również mieszkańcy miasta, wznosząc na jego cześć ołtarz, o czym sami mu donieśli. O związanym z tym zabawnym wydarzeniu wspomina Kwintylian: „mieszkańcy Tarragony donieśli Augustowi, że na dedykowanym mu ołtarzu wyrosła palma. Wygląda na to - odrzekł [cesarz] - że nie przydaje wam się zbyt często" (Quintilianus, Institutio oratoria, 6, $3,77)^{15}$. Wygląd ołtarza znany jest jedynie z zachowanej z czasów Tyberiusza monety, na której widnieje wraz ze wspomnianą palmą (Ruiz de Árbulo, 2009: 160 i n.). Kwestia lokalizacji ołtarza nie została dotychczas rozstrzygnięta, choć większość badaczy skła-

14 Dio’s Roman History, 1955: 261, tłum. A. Zimnowodzka. Więcej na ten temat zob. Amela Valverde, 2015: 59; Arrayas Morales, 2004: 299; Gozalbes Cravioto, 1997: 243.

15 Institutio Oratoria by Quintilian: 481, tłum. A. Zimnowodzka. 
nia się do sytuowania go na forum kolonii (Fishwick, 2014: 350358; Ruiz de Árbulo, 2009: 168-179; Macias et al., 2009: 426).

Po śmierci Oktawiana Augusta delegacja mieszkańców Tarragony zwróciła się do Tyberiusza z prośbą o wydanie zgody na wzniesienie świątyni na cześć zmarłego cesarza. Jak wspomina Tacyt: „na budowę świątyni Augusta [...] pozwolono proszącym o to Hiszpanom, czym dano dla wszystkich prowincji przykład" (Cornelius Tacitus, Annales, 1, 78) ${ }^{16}$. O tym, że plan został wcielony w życie, świadczy wizerunek dedykowanej Augustowi świątyni (oksastylos) z potężnymi kolumnami na monetach z okresu Tyberiusza (Fishwick, 1999: 121 i n.; Macias et al., 2014: 1540 i n.; Mar et al., 2015b: 84). Ta gigantyczna budowla stanęła w najwyższym punkcie miasta, na miejscu dawnego obozu wojskowego, a obecnie katedry (Macias Solé et al., 2010: 52). Jej obecność, wraz z potężnym, wzniesionym na trzech tarasach kompleksem budowli, który od tej pory pełnił rolę Concilium provinciae Hispaniae Citerioris, podejrzewał już w latach sześćdziesiątych i dziewięćdziesiątych XX wieku Theodor Hauschild (1983a; 1972-1974; 1977: 209-212). W trakcie prowadzonych w ostatnich latach pod katedrą prac archeologicznych ustalono, że na najwyższym $z$ tarasów znajdował się kwadratowy, otoczony portykiem plac o wymiarach około sto pięćdziesiąt na sto trzydzieści metrów ${ }^{17}$, z szeroką na dwadzieścia siedem metrów świątynią ${ }^{18}$, gdzie odbywały się uroczystości religijne ku czci Augusta. Znaleziono pozostałości jej podium o grubości dwóch metrów i trzydziestu centymetrów (Macias et al., 2014: 1539), ustalono przebieg jej ściany frontowej oraz znaleziono fragmenty schodów prowadzących do wnętrza (Macias et al., 2014: 1539)19. Dostać się na ten

16 Cyt. za: Tacyt, 2004: 77.

17 Wymiary placu są przybliżone, ich wartości mogą nieznacznie różnić się w kolejnych publikacjach i są następujące: $153 \times 136 \mathrm{~m}$; zob. Ruiz de Árbulo, 2007: 29 i 35.

18 Wymiary świątyni są przybliżone, ich podane wartości różnią się w zależności od publikacji, np. $27 \times 35 \mathrm{~m}$ (zob. Macias et al., 2010: 55); 27-28 m × $39 \mathrm{~m}$ (zob. Macias et al., 2014: 1542).

19 Odkryte tam pozostałości zabezpieczono i w grudniu 2016 roku udostępniono do oglądania zwiedzającym. 
plac można było poprzez schody umieszczone w centralnej części niżej położonego tarasu (Ruiz de Árbulo, 2017: 8). Był to prostokątny, wykonany w marmurze karraryjskim plac reprezentacyjny, o wymiarach trzysta dwadzieścia na sto siedemdziesiąt pięć metrów (Ruiz de Árbulo, 2017: 8), przeznaczony do zebrań Rady Prowincjonalnej (Concilium provinciae Hispaniae Citerioris) oraz do rozstrzygania spraw dotyczących organizacji i administracji na szczeblu prowincjonalnym (Macias Solé et al., 2010: 58; Macias et al., 2009: 429). Czas powstania placu, określony na podstawie badań stratygraficznych oraz inskrypcji na piedestałach dedykowanych prowincjonalnym flamines (kapłanom; Jaczynowska, 1990: 140), określa się na drugą połowę I wieku (około roku 70; Alföldy, 1973; Macias et al., 2009: 429; McIntyre, 2016: 73 i n.). Poprzez wzniesione w narożach placu wieże, określane obecnie jako Antigua Audiencia oraz Palacio del Pretorio (lub Torre de Pilatos), a pierwotnie pełniące funkcję klatek schodowych, można się było dostać z placu reprezentacyjnego na najniższy taras tego imponującego kompleksu (Macias et al., 2009: 441 i n.; Ruiz de Árbulo, 2007: 8 i n.).

Znajdował się na nim, wybudowany za czasów cesarza Domicjana (lata 81-96), cyrk (Macias Solé et al., 2010: 54; Ruiz de Árbulo, Mar, 2001: 141-154, Mar et al., 2015b: 171-212). Do tego przewidzianego na dwadzieścia trzy tysiące widzów ${ }^{20}$ obiektu ludność Tarraco mogła dostać się poprzez usytuowaną od wschodu Porta Triumphalis, a następnie dotrzeć w różne miejsca cyrku poprzez otaczające go kryptoportyki. Od południa cyrk sąsiadował z Via Augusta, oddzielając w ten sposób górną część miasta od dolnej - właściwej Tarraco. Był długi na trzysta dziesięć metrów i szeroki na sto dwadzieścia metrów (Mar et al., 2015b: 174), przy czym wymiary areny to dwieście dziewięćdziesiąt na siedemdziesiąt siedem metrów.

W drugiej połowie I wieku, w okresie rządów Hadriana (117-138), została odnowiona świątynia Augusta. Autor w zbiorze Historia Augusta pisze, że Hadrian „[...] podążył do

20 Dane są przybliżone, różnią się w zależności od publikacji, zob. Macias et al., 2010: 60. 
Hiszpanii i spędził zimę w Tarrakonie, gdzie własnym kosztem odbudował świątynię Augusta" (Historia Augusta, Hadrianus, $12,3)^{21}$. Na ten okres datuje się znalezione w tych okolicach fragmenty dekoracji z marmuru prokonezyjskiego (Mar et al., 2015b: 85).

Na początku II wieku n.e. miało miejsce apogeum rozkwitu rzymskiej Tarraco Istniały wówczas w mieście ważne budowle administracyjne i religijne: forum kolonii, siedziba Concilium Provinciae Hispaniae Citerioris oraz świątynie ${ }^{22}$. Funkcjonowały obiekty służące do rozrywek: teatr i cyrk, a także wzniesiony extra muros na początku II wieku amfiteatr (Mar et al., 2015b: 213237; Macias Solé, 2000: 260; Sánchez Real, 1997: 33-103; Dupré, 1994: 79-89). Jego pozostałości zostały odsłonięte po dziewięciu latach intensywnych prac (1948-1957) prowadzonych pod kierunkiem Samuela Ventury Solsony (Ventura, 1954, 259-280; Mar et al., 2015b: 213). Przeznaczony był dla czternastu tysięcy widzów. Jego fundatorem był nieznany z imienia flamen Romae Divorum et Augustorum provinciae Hispaniae Citerioris, o czym informuje wykonana na marmurowej płycie dedykacyjnej inskrypcja (Mar et al., 2015b: 218). W obrębie amfiteatru odkryto niewielką kaplicę, w której zachowało się malowidło z wizerunkiem bogini Nemezis, patronki gladiatorów. Znaleziono tam również niewielki ołtarzyk wotywny, który ofiarowali bogini niejaki Cornelius Senecianus i Valeria Pompeya w podziękowaniu za zdrowie syna (Mar et al., 2015b: 232).

Świadectwa epigraficzne i archeologiczne dowodzą, że w połowie II wieku zaczyna się stagnacja miasta, Tarraco przestaje

21 The Scriptores Historiae Augustae, 1991: 37.

22 Był to zespół delegatów ze wszystkich kolonii jednej prowincji rzymskiej, którzy raz do roku spotykali się w jej stolicy - Tarraco, aby wziąć udział w uroczystościach ku czci cesarza, którym przewodniczył flamen (kapłan rzymski, wybierany przez radę raz do roku). Rada podczas zebrań dyskutowała nad bieżącymi problemami prowincji, głosowała kształt petycji przekazywanych cesarzowi, wybierała delegatów do Rzymu, którzy prosili o pomoc w rozwiązywaniu problemów administracyjnych; zob. Jaczynowska, 1990: 112; Cary, Scullard, 1992: 51-55. 
się rozwijać. Zatrzymał się proces budownictwa willi podmiejskich. Pod koniec II wieku przestano użytkować także teatr (Macias Solé, 2010: 260). Jeszcze na początku III wieku dokonano restauracji i przebudowy niektórych reprezentacyjnych budowli. W zbiorze Historia Augusta można przeczytać, że w tym czasie

[...] wysłano Sewera do Hiszpanii; tam śniło mu się, że najpierw kazano mu odbudować świątynię Augusta w Terrakonie, chylącą się już ku upadkowi, a potem ze szczytu najwyższej góry patrzył na świat i Rzym, podczas gdy prowincje śpiewały przy dźwięku liry lub fletu (Historia Augusta, Severus, 3) ${ }^{23}$.

Z tych słów wynika, że świątynia za czasów Septymiusza Sewera (193-211) popadała w ruinę, po raz ostatni zatem doczekała się odnowy. W 218 roku cesarz Heliogabal (218-222) dokonał przebudowy amfiteatru, $\mathrm{w}$ tym poszerzenia fossae (Mar et al., 2015b: 219). W czasie prac budowlanych w najwyższej części umocowano otaczającą całą budowlę inskrypcję na cześć Heliogabala, wykonaną na pięćdziesięciu dwóch kamiennych elementach. Była to, zdaniem Alföldiego, najdłuższa inskrypcja w całym cesarstwie (Mar et al., 2015b: 2015b: 218). W połowie III wieku, w wyniku prześladowań za panowania cesarza Waleriana (253-260), w amfiteatrze zginęli śmiercią męczeńską biskup Fruktuoz i jego dwaj diakoni (Passio Fructuosi, Augurii et Eulogii, 7; il. 4) ${ }^{24}$. W konsekwencji tego zdarzenia, w IV wieku na obrzeżach miastach narodził się kult tych trzech męczenników, co miało doniosły wpływ na późniejsze przekształcenia w tkance miejskiej Tarragony (Luongo, 2010: 255-280, zwł. 258 i 280; Castillo Maldonado, 1999: 382; Wipszycka, Starowieyski, 1991: 305).

W drugiej połowie III wieku coraz bardziej widoczne było spowolnienie urbanizacyjne, zapoczątkowane już w poprzednim stu-

23 The Scriptores Historiae Augustae, 1991: 375 i n.

24 Fábrega Grau, 1953: 183-186. Por. Musurillo, 1972: 176-185. 
leciu. Przestały funkcjonować budowle „rozrywkowe”: w początkach IV wieku amfiteatr, a około połowy V wieku cyrk (Jiménez Sánchez, 2003: 376). W tym samym czasie, w IV lub V wieku, opuszczone zostało forum kolonii (Mar et al., 2015b: 213; Jiménez Sánchez, 2003: 376), a w drugiej połowie $V$ wieku rozebrano świątynię Augusta, co można uznać za wymowne „przypieczętowanie” końca pewnej epoki w dziejach miasta.

Tymczasem jednak zaczęły się ważne zjawiska urbanistyczne, związane z kultem miejscowych męczenników. Pod koniec IV wieku, extra muros, nad grobem Fruktuoza, Augriusza i Eulogiusza, wzniesiono bazylikę oraz zespół ściśle związanych z nią budowli ${ }^{25}$. W połowie VI wieku powstała również upamiętniająca ich bazylika w miejscu, gdzie zginęli, czyli w amfiteatrze (Guidi-Sánchez, 2009: 757-793). Kościoły zbudowano również w obrębie murów miejskich i miasto zaczęło przybierać nowy kształt. Temat ten jednak, choć fascynujący, czeka na opracowanie w formie kolejnego artykułu.

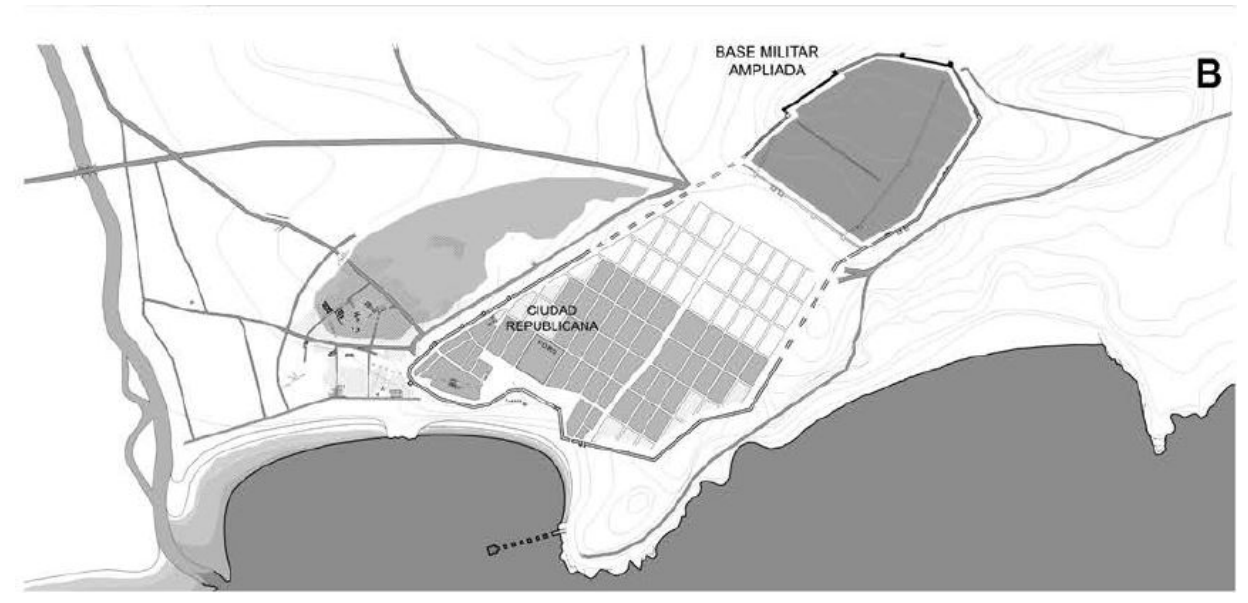

Ilustracja 1. Tarraco w II wieku p.n.e.

Źródło: Mar et al., 2015b: 78

25 Wyniki badań zostały opublikowane w czterech sprawozdaniach (Memorias) w latach 1928, 1929, 1930 i 1935 - zob. Serra Vilaró, 1928; 1929; 1930; 1935. Por. Serra Vilaró, 1937: 243-280. 


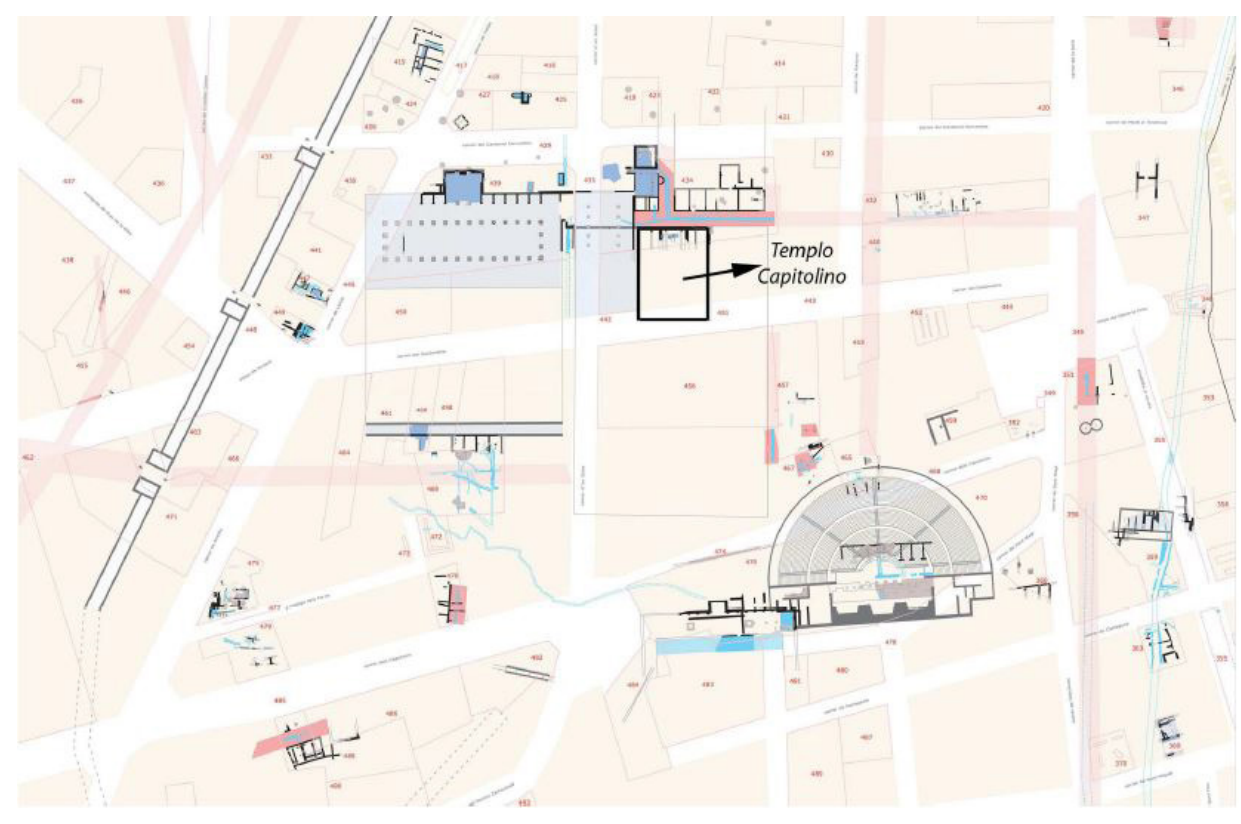

Ilustracja 2. Dolna część miasta z okresu republiki (II-I wiek p.n.e.)

Źródło: Macias et al., 2010: 52

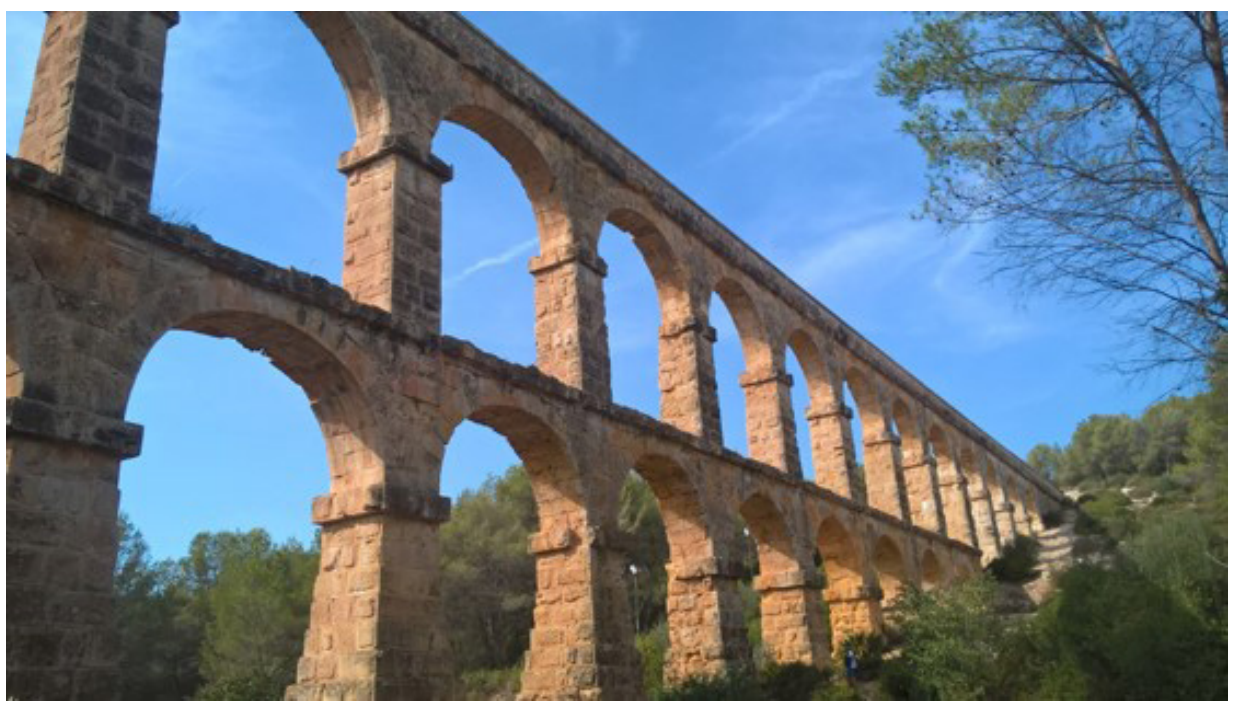

Ilustracja 3. Akwedukt Les Ferrers (fot. A. Zimnowodzka) 


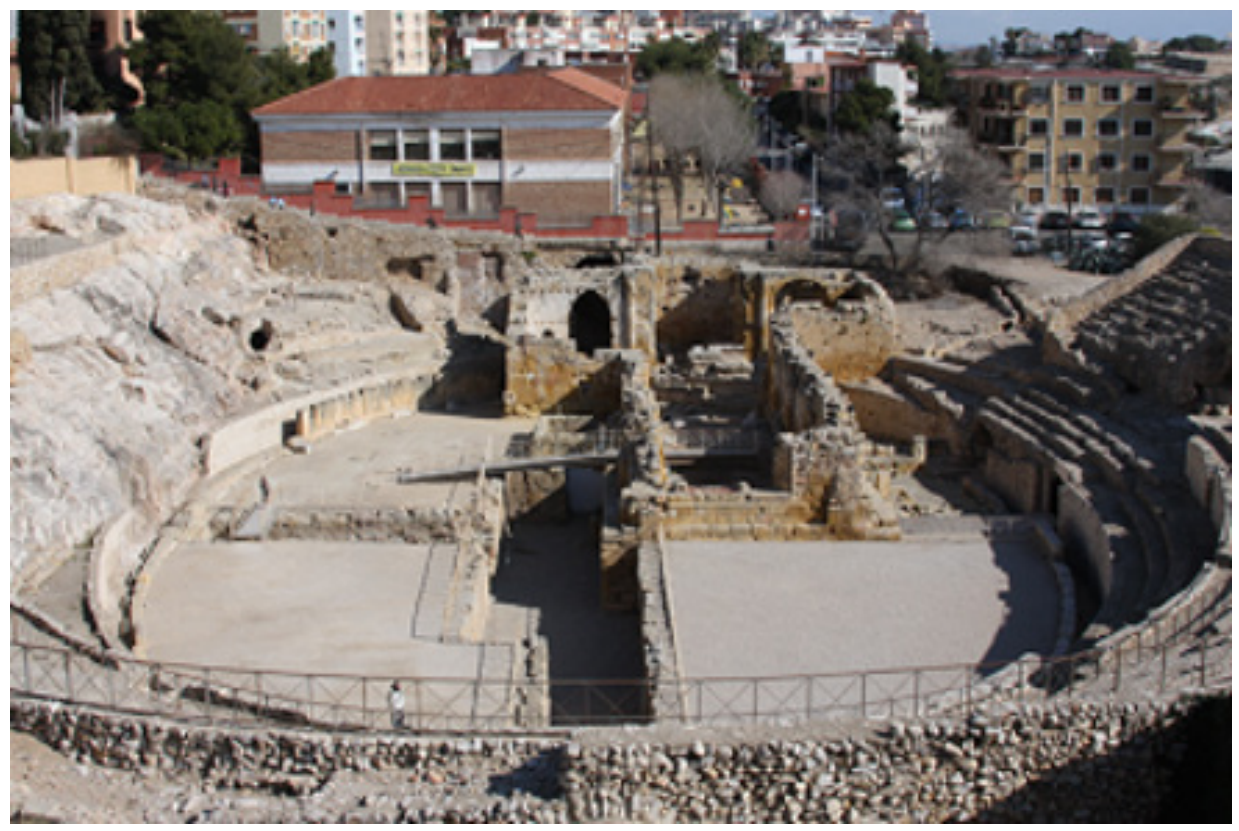

Ilustracja 4. Amfiteatr (fot. A. Zimnowodzka)

\section{Bibliografia}

Akta świętych męczenników: biskupa Fruktuoza i diakonów Auguriusza i Eulogiusza (1987), tłum. A. Malinowski. Vox Patrum 17: 764-766.

Alföldy, G. (1976): "Flamines Provinciae Hispaniae Citerioris". AEspA 6.

Amela Valverde, L. (2015): “Tarraco tardorepublicana”. Hispania Antiqva 39:

47-70.

Arrayas Morales, I. (2004), “Tarraco, capital provincial”. Gerión 22 (1): 293303.

Aquilué Abadias, X., Dupré, X., Masso Carballido, J., Ruiz de Árbulo, J. (1991):

"La cronología de las murallas de Tarraco". Revista d'Arqueologia de Ponent 1:271-301.

Bravo Bosch, M .J. (2008): “La reorganización administrativa de Hispania con César y Augusto". Revue Internationale des droits de l'Antiquité 55: 107-137.

Castillo Maldonado, P. (1999): Los mártires hispanorromanos y su culto en la Hispania de la Antigüedad Tardía. Granada: Universidad de Granada.

Díaz García, M. (1997-1998): “La Tarraco republicana. Estado de la cuestión”. ButArq 19-20: 122-135.

Topografia rzymskiej Tarragony w świetle źródeł... 
Dio's Roman History (1925), tłum. E. Cary. New York: Heinemann/Putnam Sons. Fábrega Grau, A. (red.) (1953): Pasionario Hispánico (siglos VII-IX), t. 2. Madrid/Barcelona: Instituto P. Enrique Flórez.

Fishwick, D. (1999): “The Temple of Augustus at Tarraco”. Latomus 58 (1): 121-138.

Fishwick, D. (2014): "The status and location of the altar of Augustus at Tarraco". Phoenix 68 (3-4): 350-358.

García y Bellido, A. (1959): “Las colonias romanas de Hispania”. AHDE 29: 447-512.

Gavaldà Ribot, J. M., Muñoz Melgar A., Puig i Tàrrech, A. (eds.) (2010): Pau, Fructuós i el cristianisme primitiu a Tarragona (segles I-VIII). Tarragona: Fundació Privada Liber.

The Geography of Strabo. Books III-IV (1949), Vol. 2, trans. H. L. Jones. London/Cambridge/Massahussets: William Heinemann/Harvard University Press.

Gozalbes Cravioto, E. (1997): "Los baños y la curación de Octavio Augusto en Tarraco". W: Termalismo Antiguo. Actas del I Congreso Peninsular. Madrid: Universidad Nacional de Educación a Distancia, 241-245.

Guidi-Sánchez, J. J. (2009): "Spolia et varietas, la construcción de los complejos cristianos de Tarraco. El caso de la basílica del anfiteatro". ButArq 5 (32): 757-793.

Hauschild, T. (1972-1974), "Römischen Konstruktionen auf der oberen stadterrasse des antiken Tarraco". AEspA 45-47.

Hauschild, T. (1977): “La terraza superior de Tarragona: una planificación axial del siglo I d. C.". W: Segovia. Symposium de Arqueologia Romana. Barcelona: Universitat de Barcelona, 209-212.

Hauschild, T. (1983a): Arquitectura romana de Tarragona. Tarragona: Publicacions de l'Excm. Ajuntament de Tarragona.

Hauschild, T. (1983b): "La muralla y el recinto superior romano de Tarragona". ButArq 4-5: 101-139.

“Institutio Oratoria” by Quintilian (1977), t. 2, tłum. H. E. Buttler. Cambridge/ Massachusetts/London: Loeb Classical Library.

Jaczynowska, M. (1990): Religie świata rzymskiego. Warszawa: PWN.

Járrega Domínguez, R. (2004): “Tarraco Scipionum Opus. ¿Escipión Emiliano fundador de Tarraco?”. ButArq 24-26: 23-65.

Jiménez Sánchez, J. A. (2003): "Un testimonio tardío de ludi theatrales en Hispania". Gerión 21 (1): 371-377. 
K[aja] Pliniusza Starszego „Historyi naturalnej” ksiąg XXXVII (1845), t. 2, tłum. J. Łukaszewicz. Poznań: Księgarnia i Drukarnia J. Łukaszewicza.

Keay, S. (2004), “El territorio”. W: X. Dupré Raventós (ed.), Las capitales provinciales de Hispania: Colonia Iulia Urbs Triumphalis Tarraco, t. 3. Roma: Erma di Bretschneider, 97-110.

Luongo, G. (2010): “La passio Fructuosi. Un approccio storico-letterario”. W: J. M. Gavaldà Ribot, A. Muñoz Melgar, A. Puig i Tàrrech (eds.), Pau, Fructuós i el cristianisme primitiu a Tarragona (segles I-VIII). Tarragona: Fundació Privada Liber, 255-280.

Macias, J. M., Menchón, J., Muñoz, A., Teixell, I. (2009): “La construcción del recinto imperial de Tarraco (provincia Hispania Citerior)”. ButArq 5 (32): 423-479.

Macias, J. M., Menchón, J., Muñoz, A., Teixell, I. (2010): “La acrópolis Tarraco y la implantación urbana del culto imperialen la capital de la Hispania Citerior". ButArq, wydanie specjalne A/A8/4: 50-66.

Macias, J. M., Muñoz, A., Peña, A., Teixell, I. (2014): "El Templo de Augusto en Tarraco: últimas excavaciones y hallazgos”. W: J. M. Álvarez, T. Nogales, I. Rodà (eds.), Actas XVIII Congreso Internacional de Arqueología Clásica. Merida, 13-17 mayo 2013, t. 2, 1539-1543.

Macias Solé, J. M. (2000): "Tarraco en la Antigüedad tardía: un proceso simultáneo de transformación urbana e ideológica”. W: A. Ribera (ed.), Los orígenes del Cristianismo en Valencia y su entorno. Grandes temas arqueológicos 2. Valencia: Ajuntament de València, 259-271.

Macias Solé, J. M., Remolà Vallverdú, J. A. (2010): “Portus Tarraconensis (Hispania Citerior)”. ButArq, wydanie specjalne B/B7/10: 129-140.

Mar, R., Ruiz de Árbulo, J., Vivó, D. (2010a): “El foro de la colonia Tarraco entre la República y el Imperio". W: R. González Villaescusa (ed.), Simulacra Romae II: Rome, les capitales de province (capita provinciarum) et la création d'un espace commun européen: une approche archéologique. Reins: Société archéologique champenoise, 39-70.

Mar, R., Ruiz de Árbulo, J., Vivó, D. (2010b): “Las tres fases constructivas del capitolio de Tarragona”. ButArq 32: 507-540.

Mar, R., Ruiz de Árbulo, J., Vivó, D. (2014): "El Capitolio de Tarraco". W: I. Piso, R. Varga (eds.). Trajan und seine Städte. Colloquium Cluj-Napoca, 29. September - 2. Oktober 2013. Cluj-Napoca: Mega Publishing House: 37-68.

Mar, R., Ruiz de Árbulo, J., Vivó, D., Beltrán-Caballero, J. A. (2015a): Tarraco. Arquitectura y urbanismo de una capital provincial romana, t. 1. Tarragona: Universitat Rovira i Virgili. 
Mar, R., Ruiz de Árbulo, J., Vivó, D., Beltrán-Caballero, J. A. (2015b): Tarraco. Arquitectura y urbanismo de una capital provincial romana, t. 2. Tarragona: Universitat Rovira i Virgili.

Martínez Gázquez, J. M. (1987): “Tarragona y los inicios de la romanización en Hispania". ButArq 4-5: 73-86.

McIntyre, G. (2016): A family of gods: the worship of the imperial family in the Latin West. Ann Arbor: University of Michigan Press.

Musurillo H. (ed.) (1972): The Acts of the Christian Martyrs. Oxford: Clarendon Press.

Pociña López, C.A., Remolà Vallverdú, J.A. (2001): “Nuevas aportaciones al conocimiento del Puerto de Tarraco (Hispania Tarraconensis)". Sagvntvm 33: 85-96.

Polibiusz (2005): Dzieje, t. 1, tłum. S. Hammer, Wrocław/Warszawa: Ossolineum/De Agostini.

Pons d'Icart, Ll. (1573/73): Libro de las grandezas y cosas memorables de la metropolitana, insigne y famosa ciudad de Tarragona. Llerida: Pedro e Robles y Juande Villanueva.

Remolà Vallverdú, J. A. (2007): “La imatge de Tarraco recuperada”. W: L’Antiguitat Clàssica a través dels gravats. Els Piranesi de Montserrat. Tarragona: Edició del Museu Nacional Arqueològic de Tarragona, 47-65.

Ruestes i Bitrià, C. (2001): L'espai públic a les ciutats romanes del conuentus Tarraconensis: Els fòrums (Documents). Barcelona: Bellaterra.

Ruiz de Árbulo, J. (1992): "Tarraco, Carthago Nova y el problema de la capitalidad en la Hispania Citerior Republicana”. W: X. Dupré y Raventós (ed.), Miscellània Arqueològica a Josep M. Recasens. Tarragona: Edicions El Mèdol, 115-130.

Ruiz de Árbulo, J. (2002): "La fundación de la colonia Tárraco y los estandartes de César”. W: J. L. Jiménez, A. Ribera (eds.), Valencia y las primeras ciudades romanas de Hispania. Valencia: Ayuntament de Valencia: 137-156.

Ruiz de Árbulo, J. (2007): "Nuevas cuestiones en torno al foro provincial de Tarraco”. ButArq 29:5-66.

Ruiz de Árbulo, J. (2009): "El altar y el templo de Augusto en la colonia Tarraco. Estado de la cuestión”. W: J. M. Noguera Celdrán (ed.), Fora Hispaniae. Paisaje urbano, arquitectura, programas decorativos y culto imperial en los foros de las ciudades hispanorromanas. Murcia: Universidad de Murcia, 155-189. 
Ruiz de Árbulo, J., Mar, R. (2001): “El Circo de Tarraco. Un monumento provincial”. W: T. Nogales Basarrate, F. J. Sánchez-Palencia (eds.), El circo en Hispania romana. Actas del Congreso Internacional celebrado en el Museo Nacional de Arte Romano. Mérida, 22, 23 y 24 de marzo de 2001. Madrid: Ministerio de Educación, Cultura y Deporte, 141-154.

Ruiz de Árbulo Bayona, J. (2001-2002): "Eratóstenes, Artemidoro y el puerto de Tárraco: razones de una polémica". Revista d'arqueologia de Ponent 11-12: 87-107.

Ruiz de Árbulo Bayona, J. (2015): "Tarraco obra de los Escipiones... y algo más”. W: M. Bendala Galán (ed.), Los Escipiones Roma conquista Hispania. Alcalá de Henares: Museo Arqueológico Regional: 129-147.

Sánchez Real, J. (1997): "El método en la Arqueología tarraconense. IV. El anfiteatro. B. La arena y los fosos". Quad. Hist.Tarracon 15: 33-103.

The Scriptores Historiae Augustae (1991), Vol. 1, trans. D. Magie. Cambridge/Massahussets/London: Harvard University Press/Loeb Classical Library.

Serra Masdeu, A. I. (2014): "Juan de Santa Cruz Bertrand (Gerona, C. 1729 - Tarragona, 1785), ingeniero renovador del urbanismo en Tarragona”. Biblio 3w: revista bibliográfica de geografía y ciencias sociales 19, 1099, http:// www.ub.edu/geocrit/b3w-1099.htm [30.11.2017].

Serra Vilaró, J. (1928): "Excavaciones en la necrópolis romano-cristiana de Tarragona”. Memorias de la Junta Superior de Excavaciones y Antigüedades 93.

Serra Vilaró, J. (1929): “Excavaciones en la necrópolis romano-cristiana de Tarragona”. Memorias de la Junta Superior de Excavaciones y Antigüedades 104.

Serra Vilaró, J. (1930): "Excavaciones en la necrópolis romano-cristiana de Tarragona”. Memorias de la Junta Superior de Excavaciones y Antigüedades 111.

Serra Vilaró, J. (1935): "Excavaciones en la necrópolis romano-cristiana de Tarragona". Memoria de la Junta Superior del Tesoro Artístico 133

Serra Vilaró, J. (1937): "I sepolcri della necropoli di Taragona”. RivAC 14: 243-280.

Tytus Liwiusz (1974), Dzieje Rzymu od założenia miasta, tłum. M. Brożek, Wrocław/Warszawa/Kraków/ Gdańsk: Ossolineum.

Ventura, S. (1954): "Noticias de las excavaciones en curso en el Anfiteatro de Tarragona”. AEspA 27: 259-280.

Topografia rzymskiej Tarragony w świetle źródeł... 


\section{Wykaz skrótów}

\begin{tabular}{|c|c|}
\hline AEspA & - „Archivo Español de Arqueología”, 1940- \\
\hline AHDE & $\begin{array}{l}\text { - „Anuario de historia del derecho español”, } \\
\text { 1924- }\end{array}$ \\
\hline nejos de AEspA & $\begin{array}{l}\text { - „Anejos de Archivo Español de Arqueología”, } \\
\text { 1951- }\end{array}$ \\
\hline ButArq & - Butlletí Arqueològic”, 1997- \\
\hline CUPAUAM & $\begin{array}{l}\text { - „Cuadernos de Prehistoria y Arqueología Uni- } \\
\text { versidad Autónoma de Madrid", 1974- }\end{array}$ \\
\hline
\end{tabular}

Quad.Hist.Tarracon. - „Quaderns d'Història Tarraconense”, 19771997 